\title{
ZAŠTITA I ODGOVORNOST ZA ŠTETU OD MOBINGA NA RADU I U VEZI S RADOM
}

Trpimir Perkušić, mag. iur*

\author{
UDK 364.271: 347.426 .6 \\ https://doi.org/10.30925/zpfsr.42.3.14 \\ Ur.: 26. travnja 2021. \\ Pr.: 28. lipnja 2021. \\ Pregledni rad
}

\begin{abstract}
Sažetak
Zakonska normativa u hrvatskom pravu nedorečena je i po osnovi jasnoga pojmovnog određenja $i$ zaštite od psihičkog zlostavljanja / ponižavanja, maltretiranja / radnika na radnom mjestu koje pravna doktrina i sudska praksa naziva mobingom i po osnovi odgovornosti za štete koje su nastale na radu $i$ u vezi s radom. U radu se stoga ovi pravni odnosi analiziraju u kontekstu šire normative koja se na njih može primijeniti, te tako odgovoriti na otvorena pitanja u pravnoj doktrini i sudskoj praksi. Ujedno se prema rezultatima provedene analize sagledavaju de lege ferenda moguća rješenja.
\end{abstract}

Ključne riječi: mobing; zaštita od mobinga na radu $i$ u vezi s radom; odgovornost za štetu prouzročenu mobingom na radu $i$ u vezi s radom.

\section{1. $U V O D$}

U skladu s odrednicama na kojima se temelji zaštita ljudskih prava i temeljnih sloboda prema Ustavu Republike Hrvatske ${ }^{1}$ te provodeći obveze koje proizlaze iz međunarodnih pravnih izvora, posebno onih o usklađivanju propisa s pravnom stečevinom Europske unije, ${ }^{2}$ Zakon o suzbijanju diskriminacije ${ }^{3}$ obuhvaća opća pravila kojima se osigurava i promiče jednakost, stvaraju pretpostavke za ostvarivanje jednakih mogućnosti i uređuje zaštita od diskriminacije. ${ }^{4}$ Polazeći od posebnih

* Trpimir Perkušić, mag. iur., asistent, Sveučilište u Splitu, Pravni fakultet; trpimir.perkusic@ pravst.hr. ORCID: https://orcid.org/0000-0003-4561-9926.

1 Čl. 3. i 14. Ustava Republike Hrvatske, Narodne novine, br. 56/90., 135/97., 8/98., 113/00., 124/00., 28/01., 41/01., 55/01., 76/10., 85/10., 5/14. (dalje: Ustav RH).

2 O zabrani i zaštiti od diskriminacije u okviru temeljnih prava Europske unije, vidjeti šire: Snježana Vasiljević i Mario Vinković, Temeljna prava i zabrana diskriminacije u praksi europskih i nacionalnih sudova (Zagreb: Narodne novine, 2019.), 7-40.

3 Zakon o suzbijanju diskriminacije, Narodne novine, br. 85/08., 112/12. (dalje: ZSD).

4 Odredbe kojima se zabranjuje diskriminacija sadrže i brojni drugi propisi kao što su: Ustavni zakon o pravima nacionalnih manjina, Narodne novine, br. 155/02., 47/10., 80/10., 93/11.; Zakon o ravnopravnosti spolova, Narodne novine, br. 82/08., 125/11., 20/12., 138/12., 69/17. i 
obilježja radnog odnosa (ponajprije zaštitnoga karaktera toga pravnog odnosa u kojem prisilne zakonske odredbe uređuju određena prava i obveze ispod kojih ugovorne strane ne smiju ići) i smjernica na koje upućuju prihvaćene konvencije Međunarodne organizacije rada, zakonska normativa iz područja radnih odnosa posebno u odnosu na opća pravila ZSD-a uređuje zabranu diskriminacije na području rada i obveze poslodavca i na osnovi osiguravanja uvjeta za rad na siguran način koji ne ugrožavaju zdravlje radnika i zaštite dostojanstva radnika. Riječ je ponajprije o Zakonu o radu ${ }^{5} \mathrm{i}$ Zakonu o zaštiti na radu ${ }^{6}$ koji predstavljaju opći pravni režim radnih odnosa. ${ }^{7}$ Ujedno su to polazišta, zbog kojih je navedenom normativom posebno u odnosu na opća pravila Zakona o obveznim odnosima ${ }^{8}$ u pojedinim područjima uređena odgovornost za štete nastale na radu i u vezi s radom. Međutim, navedeni su propisi nedorečeni i po osnovi zaštite psihičkoga zlostavljanja / ponižavanja, maltretiranja / radnika na radnom mjestu koje pravna doktrina i sudska praksa naziva mobingom i po osnovi odgovornosti za štete koje su nastale na radu i u vezi s radom. Tako nedorečeni propisi ne odgovaraju na više otvorenih pitanja koja u praksi otvaraju daljnje dvojbe i u ostvarivanju prava radnika kod zaštite od mobinga na radu i u vezi s radom i kod ostvarivanja prava na popravljanje štete prouzročene ovom štetnom radnjom. Zbog toga ne predstavljaju odgovarajuće pravno uređenje koje može zadovoljiti pozitivnopravne zahtjeve vladavine prava kod ostvarivanja učinkovite pravne zaštite od mobinga na radu i u vezi s radom te kod popravljanje štete prouzročene ovom štetnom radnjom.

Cilj je ovog rada analizirati posebne i opće de lege lata normative kojom se u hrvatskom pravu ovi pravni odnosi uređuju, analizu na njoj utemeljene sudske prakse, upozoriti na postojeće nedostatke pravnog uređenja (sve uz do sada izneseni pristup i shvaćanja pravne doktrine) te ponuditi odgovarajuća rješenja de lege ferenda koja će omogućiti učinkovitu pravnu zaštitu od mobinga na radu i u vezi s radom i popravljanje štete prouzročene ovom štetnom radnjom. Hipoteze istraživanja ovog rada su: ovi propisi u hrvatskom pravu ne predstavljaju odgovarajuće pravno uređenje koje može zadovoljiti pozitivnopravne zahtjeve vladavine prava kod ostvarivanja učinkovite pravne zaštite i odgovornosti za štetu te da bi pravno uređenje zadovoljavalo pozitivnopravne zahtjeve vladavine prava kod ostvarivanja učinkovite pravne zaštite, nužno je izmijeniti i dopuniti propise koji ovo područje uređuju kako bi se odgovorilo na otvorena pitanja u primjeni ovog instituta u pravcu analize na

Zakon o životnom partnerstvu osoba istog spola, Narodne novine, br. 92/14., 98/19.

5 Zakon o radu, Narodne novine, br. 93/14., 127/17., 98/19. (dalje: ZR).

6 Zakon o zaštiti na radu, Narodne novine, br. 71/14., 118/14., 154/14., 118/14., 154/14., 94/18., 96/18. (dalje: ZZR).

7 Izvan ovih zakona koji su opći pravni režim radnih odnosa, poseban pravni režim među uređuju: Zakon o državnim službenicima, Narodne novine, br. 92/05., 140/05., 142/06., 77/07., 107/07., 27/08., 34/11., 49/11., 150/11., 34/12., 38/13., 377/13., 1/15., 138/15., 61/17., 70/19., 98/19.; Zakon o službenicima i namještenicima u lokalnoj i područnoj (regionalnoj) samoupravi, Narodne novine, br. 86/08., 61/11., 4/18., 96/18., 112/19.; Zakon o policiji, Narodne novine, br. 34/11., 130/12., 151/14., 33/15., 121/16., 66/19.; Zakon o službi u Oružanim snagama Republike Hrvatske, Narodne novine, br. 73/13., 75/15., 50/16., 30/18., 125/19.

8 Zakon o obveznim odnosima, Narodne novine, br. 35/05., 41/08., 125/11., 78/15., 29/18. (dalje: ZOO). 
koju ovaj rad upućuje.

\section{ZAKONSKA ZAŠTITA RADNIKA OD DISKRIMINACIJE, UZNEMIRAVANJA I POVREDE DOSTOJANSTVA RADNIKA NA DRUGI NAC̆IN}

\subsection{Pojmovno određenje i zaštita od diskriminacije, uznemiravanja kao posebnih oblika diskriminacije i povrede dostojanstva radnika na drugi način}

Pod diskriminacijom (lat. discriminare - razlučivati, dijeliti) općenito se podrazumijeva pravom zabranjeno (nedopušteno) pravljenje razlike među osobama ili skupinama osoba. ${ }^{9}$ Uređujući temeljne obveze i prava iz radnog odnosa ZR izrijekom zabranjuje izravnu ili neizravnu diskriminaciju na području rada i uvjeta rada, uključujući kriterije za odabir i uvjete pri zapošljavanju, napredovanju, profesionalnom usmjeravanju, stručnom osposobljavanju i usavršavanju te prekvalifikaciji. ${ }^{10}$ Iako se navedenom odredbom ističu područja u kojima je zabranjena diskriminacija, u pravnoj se doktrini ${ }^{11}$ utemeljeno ističe da se zabrana diskriminacije odnosi na sva prava iz radnoga odnosa, dok područja u kojima je diskriminacija zabranjena prema ZR-u treba shvatiti kao primjerična nabrajanja (lat. exempli gratiae). Naime, u dijelu kojim zakonska normativa iz područja radnih odnosa posebno ne uređuje zabranu diskriminacije na području rada primjenjuju se opća pravila ZSD-a. U njima se pod diskriminacijom podrazumijeva stavljanje u nepovoljniji položaj bilo koje osobe, kao i osobe povezane s njom rodbinskim ili drugim vezama po osnovi (osnove diskriminacije): rase ili etničke pripadnosti ili boje kože, spola, jezika, vjere, političkog ili drugog uvjerenja, nacionalnog ili socijalnog podrijetla, imovinskog stanja, članstva u sindikatu, obrazovanja, društvenog položaja, bračnog ili obiteljskog statusa, dobi, zdravstvenog stanja, invaliditeta, genetskog naslijeđa, rodnog identiteta, izražavanja ili spolne orijentacije. Isto tako, pod diskriminacijom se podrazumijeva i stavljanje neke osobe u nepovoljniji položaj na temelju pogrešne predodžbe o postojanju neke od navedenih osnova za diskriminaciju. ${ }^{12}$ Prema shvaćanju iznesenom u pravnoj doktrini: diskriminacija postoji kada se zadovolje četiri elementa: slične ili podudarne grupe, različito tretiranje, prema

9 Željko Potočnjak, „Zabrana diskriminacije, uznemiravanja i spolnog uznemiravanja u radnim odnosima“, u: Radni odnosi u Republici Hrvatskoj, Željko Potočnjak (ur.) et al. (Zagreb: Pravni fakultet u Zagrebu i Organizator, 2007.), 49-53; Željko Potočnjak i Ivana Grgurev, „Odgovornost za neimovinsku štetu zbog diskriminacije na radu“, u: Odgovornost za neimovinsku štetu zbog povreda prava osobnosti $u$ vezi s radom - mobing, dostojanstvo, diskriminacija, izloženost štetnim utjecajima, ozljeda na radu, profesionalna oboljenja $i d r$., ur. Petar Klarić (Zagreb: Narodne novine, 2007.), 45-47; Vesna Barić Punda, „Načelo nediskriminacije - jedno od temeljnih načela zaštite ljudskih prava i sloboda“, Zbornik radova Pravnog fakulteta u Splitu 42, br. 1-2 (2005): 27-42.

10 Čl. 7. st. 4. ZR-a.

11 Potočnjak i Grgurev, Odgovornost za neimovinsku štetu zbog diskriminacije na radu, 56.

12 Čl. 1. ZSD-a. 
zabranjenim osnovama, bez opravdanja (bez legitimnog cilja ili neprimjeren cilju). ${ }^{13,}{ }^{14}$ ZSD razlikuje izravnu i neizravnu diskriminaciju, ${ }^{15}$ jasno se određuje o poticanju na diskriminaciju, ${ }^{16}$ segregaciji, ${ }^{17}$ teškim oblicima diskriminacije, ${ }^{18}$ zaštiti od viktimizacije ${ }^{19}$ te iznimke od zabrane diskriminacije. ${ }^{20}$ ZSD posebno uređuje zaštitu zbog diskriminacije pred sudom. ${ }^{21}$ Pritom određuje posebne tužbe za zaštitu od diskriminacije, ${ }^{22}$ ali i dokazivanje činjenica u antidiskriminacijskim sporovima kojim (u skladu s direktivama EU-a $)^{23}$ odstupa od pravila parničnog postupka o teretu dokazivanja. ${ }^{24}$ Prema tim posebnim pravilima o teretu dokazivanja, kada stranka u sudskom ili drugom postupku tvrdi da je povrijeđeno njezino pravo na jednako postupanje u skladu s odredbama toga Zakona, obvezna je učiniti vjerojatnim da je došlo do diskriminacije. Teret dokazivanja da nije bilo diskriminacije leži na protivnoj stranci (na poslodavcu). ${ }^{25}$ Riječ je o postupovnoj zaštiti žrtve diskriminacije kao slabije strane $u$ diskriminacijskom sporu, pa je kod diskriminacije na radnom odnosu radnik dužan učiniti vjerojatnim postojanje činjenica o kojima ovisi postojanje prava na jednako postupanje i povreda toga prava (od radnika se ne zahtijeva da te činjenice dokaže na stupnju izvjesnosti, već pretežnije vjerojatnosti). Teret dokazivanja da nije bilo diskriminacije prebačen je na poslodavca.

Uz izričitu zabranu diskriminacije ZR pod temeljnim obvezama i pravima iz radnog odnosa uređuje obvezu poslodavca zaštititi dostojanstvo radnika ${ }^{26}$ i kod

13 Darko Milković, „Diskriminacijski postupci u radnopravnim parnicama“, u: Zbornik radova Građansko pravo - sporna pitanja i aktualna sudska praksa - 2018. (Tuheljske Toplice: Vrhovni sud Republike Hrvatske i Pravosudna akademija, 2018.), 2.

$14 \mathrm{O}$ zaštiti od diskriminacije u praksi Europskog suda za ljudska prava vidjeti: Jasna Omejec, „Zabrana diskriminacije u praksi Europskog suda za ljudska prava“, Zbornik Pravnog fakulteta u Zagrebu 59, br. 5 (2009): 873-979.

15 Čl. 2. st. 2. ZSD-a.

16 Čl. 4. ZSD-a.

17 Čl. 5. ZSD-a.

18 Čl. 6. ZSD-a.

19 Čl. 7. ZSD-a.

20 Iznimke od zabrane diskriminacije uređuju odredbe čl. 9. st. 2. i 3. ZSD-a.

21 Čl. 16.-24. ZSD-a.

22 Čl. 17. i 24. ZSD-a.

23 Direktivom Vijeća 2000/43/EZ od 29. lipnja 2000. o provedbi načela jednakosti jednakog postupanja prema osobama bez obzira na njihovo rasno ili etničko podrijetlo, Službeni list EU 180, 19. 7. 2000. (posebno čl. 8.); Direktivom Vijeća 2000/78/EZ od 27. studenoga 2000. o uspostavi općeg okvira za jednako postupanje pri zapošljavanju i obavljanju zanimanja, Službeni list EU 303, 02. 12. 2000. (posebno čl. 10.); Direktivom Vijeća 2004/113/EZ od 13. prosinca 2004. o provođenju načela jednakog postupanja prema muškarcima i ženama u pružanju usluga, Službeni list EU 373, 21. 12. 2004. (posebno čl. 9.) i Direktivom Europskog parlamenta i Vijeća 2006/54/EZ od 05. srpnja 2006. o provedbi načela jednakih mogućnosti i jednakih postupanja prema muškarcima i ženama u pitanjima zapošljavanja i rada, Službeni list EU 204, 26. 07. 2006. (posebno čl. 19.).

24 Čl. 7. st. 1. i čl. 219. st. 1. Zakona o parničnom postupku, Narodne novine, br. 53/91., 91/92., 112/99., 88/01., 117/03., 88/05., 2/07., 84/08., 96/08., 57/11., 148/11. - proč. tekst, 25/13., 28/13., 89/14., 70/19.

25 Čl. 20. st. 1. ZSD-a.

26 O širem pojmu dostojnog rada vidjeti: Anton Petričević i Davor Medarić, „Pravo radnika na 
određivanja mjesta i načina obavljanja rada i tijekom obavljanja poslova od postupanja nadređenih, suradnika i osoba s kojima radnik redovito dolazi u doticaj u obavljanju svojih poslova, ako je takvo postupanje neželjeno i u suprotnosti s ovim Zakonom i drugim propisima. Pritom je dužan osigurati radniku uvjete za rad na siguran način i na način koji ne ugrožava zdravlje radnika u skladu s pravilima o zaštiti na radu i drugim pravilima iz ovog područja. ${ }^{27}$ Kod navedene zaštite radnika, ZR svojim odredbama poslodavcu koji zapošljava najmanje 20 radnika nalaže obvezu donošenja pravilnika o radu. Pravilnikom se, između ostalog, uređuje postupak i mjere za zaštitu dostojanstva radnika i mjere zaštite od diskriminacije, ako ta pitanja nisu uređena kolektivnim ugovorom ${ }^{28}$ te se posebno uređuje postupak i mjere zaštite dostojanstva radnika od uznemiravanja i spolnog uznemiravanja. ${ }^{29} \mathrm{U}$ tom je postupku pasivno legitimiran poslodavac, a radniku je (uz određene pretpostavke) ${ }^{30}$ omogućen i prekid rada dok mu se ne osigura zaštita. Međutim, što predstavlja uznemiravanje i spolno uznemiravanje posebno ne uređuju odredbe ZR-a, već odredbe ZSD-a kao poseban oblik diskriminacije. ${ }^{31}$ Takvo pravno uređenje, neovisno o posebnom postupovnom položaju radnika kod tereta dokaza, otežava položaj uznemiravanoga radnika u postupku zaštite njegovih prava. Naime, u postupku zaštite uz ostale pretpostavke zahtijeva se da je uznemiravanje prouzročeno nekim od zabranjenih osnova diskriminacije (nije riječ o uznemiravanju ako neželjeno ponašanje od kojeg radnik zahtijeva zaštitu nije prouzročeno nekim od zabranjenih osnova diskriminacije). ${ }^{32}$

Sustav zaštite na radu ${ }^{33}$ posebno je uređen odredbama ZZR-a. Svrha je Zakona sustavno unaprjeđivanje sigurnosti i zaštite zdravlja radnika i osoba na radu, sprječavanje ozljeda na radu, profesionalnih bolesti i bolesti u vezi s radom. Propisuje opća načela sprječavanja rizika na radu i zaštite zdravlja, pravila za uklanjanje čimbenika rizika, postupke osposobljavanja radnika te postupke obavješćivanja i savjetovanja radnika $\mathrm{i}$ njihovih predstavnika s poslodavcima i njihovim ovlaštenicima. ${ }^{34}$ Kod tumačenja sustava zaštite na radu u smislu Zakona treba se pozvati na zaključno shvaćanje izneseno u pravnoj doktrini prema kojem: zaštitu na

dostojanstven rad i radno okruženje bez stresa“, Pravni vjesnik: časopis za pravne i društvene znanosti Pravnog fakulteta Sveučilišta J.J. Strossmayera u Osijeku 30, br. 2 (2014): 405-417., Ustavni sud Republike Hrvatske se u više svojih odluka izjasnio o zaštiti dostojanstva radnika (U-III-3519/2018 od 7. listopada 2020. odlomak 21.-30.), U-III-1095/2014 od 21. rujna 2017. (odlomak 11.-21.) i broj: U-III-6791/2014 od 30. svibnja 2018. (odlomak 4.10.).

27 Čl. 7. st. 2., 3. i 5. ZR-a.

28 Čl. 26. st. 1. ZR-a.

29 Čl. 134. st. 1.-3. ZR-a.

30 Čl. 134. st. 4. i 5. ZR-a.

31 Čl. 3. st. 1.-3. ZSD-a.

$32 \mathrm{~S}$ obzirom na ove pretpostavke nisu iznesena različita pravna shvaćanja u sudskoj praksi (Vrhovni sud Republike Hrvatske, Revr-526/17-2 od 26. rujna 2017., Revr -35/2015-2 od 13. studenog 2019. i Revr-1761/2014-3 od 27. veljače 2019.).

33 Prema odredbi čl. 3. st. 1. t. 32. ZZR-a, zaštita na radu sustav je pravila, načela, mjera, postupaka i aktivnosti, čijom se organiziranom primjenom ostvaruje i unapređuje sigurnost i zaštita zdravlja na radu, u cilju sprječavanja rizika na radu, ozljeda na radu, profesionalnih bolesti, bolesti u vezi s radom te ostalih materijalnih i nematerijalnih šteta na radu i u vezi s radom.

34 Čl. 1. st. 1.-3. ZZR-a. 
radu pružaju poslodavci, njihovi ovlaštenici, stručnjaci zaštite na radu, odbori za zaštitu na radu, a nadziru inspektori zaštite na radu $i$ drugi državni organi. ${ }^{35}$ Tako je prema odredbama ZZR-a, ${ }^{36}$ obveza organiziranja i provođenja zaštite na radu na poslodavcu, koji je pritom dužan voditi računa o sprječavanju rizika, obavješćivanju, osposobljavanju, organizaciji i sredstvima, čime je u ovim postupcima poslodavac i odgovoran za organiziranje i provođenje zaštite na radu radnika. Na tu odgovornost ne utječu niti propisane obveze radnika u području zaštite na radu. Njegovu odgovornost ne isključuje niti činjenica da je u tu svrhu zaposlio jednog ili više stručnjaka zaštite na radu ili da je obavljanje poslova zaštite na radu ugovorio s osobom ovlaštenom za obavljanje tih poslova. ${ }^{37}$ Svojim odredbama ZZR je preuzeo osnovne institute zaštite na radu iz ranije Zakona o zaštiti na radu. ${ }^{38}$ Među važnije novele povezano $\mathrm{s}$ tematikom ovoga rada spadaju i odredbe o mjerama zaštite radnika od psihosocijalnih rizika i psihofizioloških napora na radu. ZZR uređuje obveze poslodavca, ali i obveze radnika i njihovih predstavnika u vezi sa stresom prouzročenog na radu ili u vezi s radom. ${ }^{39}$ Poslodavac je obvezan provoditi prevenciju stresa na radu ili u vezi s radom koji je prouzročen osobito čimbenicima kao što su sadržaj rada, organizacija rada, radno okruženje, loša komunikacija i međuljudski odnosi, kako bi sveo na najmanju mjeru potrebu radnika da savlada poteškoće zbog dugotrajnije izloženosti intenzivnom pritisku te otklonio mogućnost da se umanji radna učinkovitost radnika i pogorša njegovo zdravstveno stanje. ${ }^{40} \mathrm{~S}$ druge strane, radnici su obvezni postupati u skladu s uputama poslodavca za sprječavanje, uklanjanje ili smanjivanje stresa na radu ili u vezi s radom te su kao i njihovi predstavnici obvezni surađivati s poslodavcem radi sprječavanja, uklanjanja ili smanjivanja stresa na radu ili u vezi $\mathrm{s}$ radom. ${ }^{41,42}$ Međutim, kako se to utemeljeno ističe u pravnoj doktrini, ${ }^{43}$ navedenom normativom ZZR-a nije obuhvaćen pojam mobinga, jer je pojam stresa širi i obuhvaća zdravstvene i psihičke promjene do kojih je došlo zbog dugotrajnog utjecaja stresora na radu. One za razliku od mobinga ne moraju nužno biti posljedica ponašanja jedne ili više osoba prema drugoj radi ugrožavanja njezinog ugleda, časti, ljudskoga dostojanstva $\mathrm{i}$ integriteta.

35 Svjetlana Šokčević, „Zakon o zaštiti na radu s komentarima i tumačenjima (Zagreb: TIM press, 2014.), 12.

36 Čl. 17. ZZR-a.

37 Čl. 19. ZZR-a.

38 Zakon o zaštiti na radu, Narodne novine, br. 59/96., 94/96., 114/03., 100/04., 86/08., 116/08.,75/09. i 143/12. Ovaj je Zakon prestao vrijediti stupanjem na snagu ZZR-a 19. lipnja 2014.

39 Prema odredbi čl. 3. st. 1. t. 28. ZZR-a, stres na radu su zdravstvene i psihičke promjene koje su posljedica akumulirajućeg utjecaja stresora na radu kroz dulje vrijeme, a očituju se kao fiziološke, emocionalne i kognitivne reakcije te kao promjene ponašanja radnika.

40 Čl. 51. st. 1. ZZR-a.

41 Čl. 52. ZZR-a.

42 Tako: Svjetlana Šokčević, „Zaštita dostojanstva i zdravlja radnika - zaštita od maltretiranja na radu i u vezi s radom“, Sigurnost: časopis za sigurnost u radnoj i životnoj okolini 58, br. 1 (2016): 12.

43 Mario Vinković, Snježana Vasiljević i Iris Gović Penić, Priručnik o diskriminaciji i mobbingu na radnom mjestu (Zagreb: Udruga za pomoć i edukaciju žrtava mobinga, 2016.), 45-46. 
Analizom odredbi ZR-a, ZZR-a i ZSD-a proizlazi da se radnik posebno štiti od uznemiravanja (kao jednog od oblika zaštite dostojanstva radnika) samo ako je ponašanje kojim se radnik uznemirava prouzročeno nekim od osnova diskriminacije. ${ }^{44}$ Tako neželjeno ponašanje kojemu je cilj ili je stvarna povreda dostojanstva radnika i koje je kod radnika prouzročilo strah, neprijateljsko, ponižavajuće ili uvredljivo okruženje, ali nije učinjeno zbog nekog od osnova diskriminacije, ne smatra se uznemiravanjem u smislu posebne pravne zaštite prema navedenoj normativi. Tek u okolnostima ako je takvo neželjeno ponašanje kojim se radnik uznemirava izravna prijetnja i rizik za život i zdravlje radnika, prema odredbama ZZR-a, radnik ima pravo odbiti raditi i napustiti mjesto rada sve dok poslodavac ne poduzme korektivne mjere. $^{45}$

Međutim, kako se to ističe u pravnoj doktrini poslodavac mora pružiti radniku zaštitu od svih neželjenih loših ponašanja, pa i onih koja nisu diskriminatorna, uvijek kada nalazi da mogu biti prijetnja zdravlju, dostojanstvu i sigurnosti radnika na radu $i$ u vezi s radom, jer je osnovna obveza poslodavca procijeniti sve rizike na radu te zaštititi radnike od svih rizika. ${ }^{46}$ Isto je pravno shvaćanje u svojim odlukama zauzeo i Ustavni sud Republike Hrvatske ${ }^{47}$ te praksa redovitih sudova. ${ }^{48} \mathrm{U}$ tom je smislu poslodavac dužan zaštititi radnika i od uznemiravanja (zlostavljanja, maltretiranja) na radu i u vezi s radom koja nisu prouzročena niti jednim od navedenih osnova diskriminacije, a koja pravna doktrina i sudska praksa naziva mobingom.

\subsection{Pojmovno određenje i zaštita od mobinga na radu i u vezi s radom u pravnoj doktrini i sudskoj praksi}

Mobing (engl. mobbing) $)^{49}$ uključuje psihičko uznemiravanje na radnom mjestu po bilo kojem temelju ${ }^{50} \mathrm{i}$ u pravnoj se doktrini određuje kao specifičan oblik ponašanja na radnom mjestu kojim jedna osoba ili skupina njih sustavno psihički (moralno) zlostavlja i ponižava drugu osobu s ciljem ugrožavanja njezina ugleda, časti, ljudskog dostojanstva i integriteta, sve do eliminacije s radnog mjesta. Takve se aktivnosti smatraju mobingom ako su učestale, odnosno ako traju određeno

44 Dakle, samo ako je prouzročeno zbog nekog od diskriminirajućih osnova iz odredbe čl. 1. st. 1. ZSD-a.

45 Čl. 69. st. 4. ZZR-a.

46 Šokčević, Zaštita dostojanstva i zdravlja radnika - zaštita od maltretiranja na radu i u vezi s radom, 6 i 7.

47 Ustavni sud Republike Hrvatske (U-III-4639/2005 od 5. listopada 2006. (odlomak 4.) i U-III-6791/2014 od 30. svibnja 2018. (odlomak 4.-10.)).

48 Tako, prema odluci Vrhovnog suda Republike Hrvatske, Revr-552/05 od 28. prosinca 2005., poslodavac je dužan osigurati radniku uvjete za siguran rad u skladu s posebnim zakonom i drugim propisima.

49 Izraz potječe od engleskoga glagola to mob, što se može prevesti kao bučno navaliti, nasrnuti u masi.

50 Potočnjak i Grgurev, Odgovornost za neimovinsku štetu zbog diskriminacije na radu, 69., Andreja Kostelić Martić, Mobing: psihičko maltretiranje na radnom mjestu (Zagreb: Školska knjiga, 2005.), 11. 
vrijeme..$^{51,52}$

Slično pojmovno određenje mobinga te osnove zaštite radnika od mobinga na radu i u vezi s radom, sudska praksa temelji na širem povezanom tumačenju odredbi prethodno navedenih zakona: mobing je specifični oblik ponašanja na radnom mjestu kojim jedna osoba ili skupina njih sustavno psihički (moralno) zlostavlja i ponižava drugu osobu s ciljem ugrožavanja njezina ugleda, časti, ljudskog dostojanstva $i$ integriteta, sve do eliminacije s radnog mjesta. ${ }^{53}$

Prema pravnom shvaćanju Ustavnog suda Republike Hrvatske: pojam mobinga uključuje svaku vrstu psihofizičkog zlostavljanja ili uznemiravanja na radnom mjestu, neovisno o tome je li ono uzrokovano nekom od zabranjenih diskriminacijskih osnova iz ZSD-a ili pak ne proizlazi iz takve osnove već je riječ o zlostavljanju iz nekih drugih motiva... (...) ...svatko ima pravo na zaštitu od uznemiravanja. Svaka osoba, pa tako i svaki radnik, to pravo ima temeljem odredbe članka 1048. ZOO-a, prema kojoj svatko ima pravo zahtijevati od suda ili drugoga nadležnog tijela da naredi prestanak radnje kojom se povređuje pravo njegove osobnosti i uklanjanje njome izazvanih posljedica. ${ }^{54}$

Iz toga proizlazi da je u nedostatku dorečene zakonske normative, pravna doktrina i sudska praksa izgradila jasno pojmovno određenje mobinga na radu i u vezi s radom. S druge strana, pravna zaštita radnika od mobinga može se ostvarivati tek širim tumačenjem i odredbi ZR-a i ZZR-a koje uređuju prava i obveze iz radnog odnosa i općih odredbi ZOO-a koje se odnose na zaštitu subjektivnih prava. ${ }^{55}$ Međutim, uz pravo radnika na zaštitu dostojanstva od neželjenoga postupanja koje predstavlja mobing na radu i u vezi s radom kao temeljnoga prava iz radnog odnosa, navedena je zaštita i u interesu poslodavca (smanjenih gubitaka po osnovi izostanka radnika s posla (bolovanje), smanjenih pogrešaka na radu, povećanje radne motivacije, povećanje radnog učinka i sl.). Navedeni razlozi upućuju na potrebu de lege ferenda izmjene i dopune ZR-a kojima će se u skladu s već zauzetim pravnim shvaćanjima u pravnoj doktrini i sudskoj praksi pojam mobinga na radu i u vezi s radom jasno odrediti način kojim ovaj oblik zaštite dostojanstva radnika nije vezan uz zabranjene osnove diskriminacije (jer riječ je o mobingu i kada on ne proizlazi iz nekog od zabranjenih osnova diskriminacije koje propisuje ZSD), a radniku kod zaštite omogućiti prava propisana u zaštiti od uznemiravanja i spolnog uznemiravanja, a kako je to preciznije naznačeno u zaključku ovog rada.

51 Milković, Diskriminacijski postupci u radnopravnim parnicama, 8; slično Iris Gović Penić, „Nova sudska praksa na području uznemiravanja/ diskriminacije i mobinga“, Radno pravo br. 10 (2018): 3.

52 O vrstama mobinga vidjeti: Renata Pražetina Kaleb, „Oblici mobinga i sudska zaštita žrtava mobinga“, Policija i sigurnost 21, br. 4 (2012): 823-836.

53 Županijski sud u Zagrebu, Gž R-404/16 od 12. siječnja 2017. Slično Vrhovni sud Republike Hrvatske, Revr-526/17-2 od 26. rujna 2017.

54 Ustavni sud Republike Hrvatske, U-III-6791/2014 od 30. svibnja 2018. (odlomak 4.-10.).

55 Kod zaštite od radnji koje predstavljaju mobing riječ je o odredbama čl. 8. i 1048. ZOO-a, a kada je riječ o popravljanju štete prouzročene mobingom o odredbama čl. 342.-349. i čl. 1045.1109. ZOO-a, koje se primjenjuju u skladu s odredbom čl. 111. ZR-a. 


\section{ODGOVORNOST ZA S̆TETU KOJA JE RADNIKU NA RADU I U VEZI S RADOM PROUZROČENA DISKRIMINACIJOM, UZNEMIRAVANJEM I POVREDOM DOSTOJANSTVA NA DRUGI NAČIN}

Uvažavajući bitna obilježja radnog odnosa (dobrovoljnost zasnivanja radnog odnosa, podređenost radnika uputama poslodavca, obveza osobnog obavljanja rada i naplatnost), posebno zaštitni karakter toga pravnog odnosa, odredbama ZR-a i ZZR-a posebno je uređena odgovornost za štete nastale na radu i u vezi s radom u odnosu na opća pravila obveznog prava o odgovornosti za štetu iz ZOO-a. Na opća pravila ZOO-a o odgovornosti za štetu svojim odredbama upućuje i ZSD. U tom se smislu opće odredbe ZOO-a kod ove odgovornosti primjenjuju tek supsidijarno, tj. ako nisu s tim posebnim pravnim uređenjem u suprotnosti (lat. lex specialis derogat legi generali). Pritom je nužno voditi računa da ZR uređuje radni odnos u Republici Hrvatskoj ako drugim zakonom ili međunarodnim ugovorom nije drukčije određeno, ZZR posebno uređuje sustav zaštite na radu, dok je cilj ZSD-a posebno osigurati i promicati zaštitu jednakosti kao najviše vrednote ustavnog poretka Republike Hrvatske, stvoriti pretpostavke za ostvarenje jednakih mogućnosti te urediti zaštitu od diskriminacije. Stoga, kada je riječ o odgovornosti za štetu prouzročenu mobingom, svaku od navedenih pravnih normi treba tumačiti povezujući je i dopunjujući ponajprije s drugim normama iz zakona koju tu vrstu pravnog odnosa posebno uređuje, ali povezujući je i s drugim normama iz pravnoga sustava.

\subsection{Posebno pravno uređenje odgovornosti za štetu prema odredbama ZR-a, ZZR-a i ZSD-a}

Odgovornost poslodavca za štetu koju je radnik pretrpio na radu ili u vezi s radom, u okolnostima kada ta odgovornost nije uređena posebnim pravilima, sagledava se prema pravilima ZR-a koja upućuju na primjenu općih propisa obveznog prava. ${ }^{56}$ Pritom se posebno uređuje da se pravo na naknadu štete odnosi i na štetu koju je poslodavac prouzročio radniku povredom njegovih prava iz radnog odnosa. Riječ je o radnom odnosu, pa su subjekti odgovornosti za štetu radnik kao oštećenik i poslodavac kao odgovorna osoba. Da bi došlo do odgovornosti za štetu u smislu ovih posebnih pravila, uz opće pretpostavke odgovornosti za štetu (subjekti odgovornosti za štetu, protupravna štetna radnja, nastup štete te uzročna veza između štetne radnje $i$ štete), treba biti ispunjena i posebna pretpostavka da je radnik pretrpio štetu na radu ili u vezi s radom. Kod odgovora na pitanje je li određena šteta nastala na radu i u vezi s radom, bitno je odrediti pravni odnos između osoba koje su izravno sudjelovale u štetnom događaju (štetnik, oštećenik) te u pojedinim okolnostima između tih osoba i osoba koje su na određeni pravno relevantan način povezane s osobama koje su izravno sudjelovale u tom štetnom događaju (radnik i poslodavac, izvođač i naručitelj posla, nalogoprimac i nalogodavac i sl.). Bitna obilježja radnog odnosa (podređenosti radnika uputama poslodavca, obveze osobnog obavljanja rada i naplatnosti) elementi 
su prema kojima radni odnos treba razlikovati od sličnih pravnih odnosa koji za svoj predmet imaju određenu činidbu rada (npr. pravnog odnosa koji proizlazi iz ugovora o djelu ili ugovora o nalogu). $\mathrm{U}$ tom smislu valja voditi računa da $\mathrm{ZR}^{57}$ uređuje pretpostavku prema kojoj se u okolnostima kada je poslodavac $\mathrm{s}$ radnikom sklopio ugovor za obavljanje posla koji, s obzirom na narav i vrstu rada te ovlasti poslodavca, ima obilježja posla za koji se zasniva radni odnos, smatra da je s radnikom sklopio ugovor o radu, osim ako poslodavac ne dokaže suprotno.

Kada je utvrđeno da je riječ o radnom odnosu, štetom koju je radnik pretrpio na radu smatra se svaka šteta koju je radnik pretrpio osobno ispunjavajući svoje radne obveze shodno sadržaju pojedinačno određenoga radnog odnosa, odnosno shodno uputama koje mu daje poslodavac prema sadržaju tako pojedinačno određenog radnog odnosa. ${ }^{58}$ Pod pojmom štete koju je radnik pretrpio u vezi s radom podrazumijeva se šire područje primjene. Ono obuhvaća i one štete koje radnik trpi postupanjem koje izravno ne obuhvaća ispunjavanje radne obveze shodno sadržaju pojedinačno određenog radnog odnosa, odnosno shodno uputama koje mu je u sklopu tog sadržaja dao poslodavac, ali je ono na određeni pravno relevantan način povezano i u funkciji $\mathrm{S}$ ispunjavanjem tih obveza. ${ }^{59}$

Kada ZR kod odgovornosti poslodavca za štetu koju radnik pretrpi na radu ili u vezi s radom upućuje na odgovarajuću primjenu općih propisa obveznog prava, ujedno ne određuje je li riječ o pravilima koja uređuju izvanugovornu (deliktnu) odgovornost za štetu ili pravilima koja uređuju odgovornosti za štetu zbog povrede prethodno postojeće obveze (ugovornu / kontraktnu odgovornost) te je li riječ o odgovarajućoj primjeni pravila o subjektivnoj (kriterij krivnje) ili objektivnoj (kriterij uzročnosti) odgovornosti. Odgovarajuća primjena općih pravila o vrsti i kriteriju odgovornosti šire se analizira u radu pod 3.2.

Kako ZZR posebno uređuje sustav zaštite na radu (vidi u radu pod 2.1.) čime su odredbe ovoga Zakona kod tumačenja odgovornosti za štete nastale na radu i u vezi $\mathrm{s}$ radom relevantne po osnovi odgovornosti poslodavca za organiziranje i provođenje zaštite radnika na radu (u smislu odgovornosti za štetu odgovoran je i za protupravnu štetnu radnju propuštanja urednog i pravodobnog organiziranja i provođenja zaštite radnika na radu). ZZR posebno uređuje i odgovornost za štete zbog ozljede na radu i profesionalne bolesti koju je radnik pretrpio obavljajući poslove za poslodavca. Prema tom posebnom pravnom uređenju, ${ }^{60}$ ozljeda na radu i profesionalna bolest koju je radnik pretrpio obavljajući poslove za poslodavca smatra se da potječe od

57 Čl. 10. st. 2. ZR-a.

58 Slično pravno shvaćanje zauzeto je u pravnoj doktrini: Ivica Crnić, „Odgovornost za štetu iz radnog odnosa i popravljanje te štete“, u: Radni odnosi u Republici Hrvatskoj, Željko Potočnjak (ur.) et al. (Zagreb: Pravni fakultet u Zagrebu i Organizator, 2007.), 273; Petar Klarić i Martin Vedriš, Građansko pravo (Zagreb: Narodne novine, 2009.), 624 i sudskoj praksi (Vrhovni sud Republike Hrvatske, Revt-133/07 od 29. travnja 2008.).

59 Slično pravno shvaćanje zauzeto je u pravnoj doktrini: Vera Babić et al., Veliki komentar novog Zakona o radu (Zagreb: Vaša knjiga, 2010.), 153; Crnić, Odgovornost za štetu iz radnog odnosa i popravljanje te štete, 273; Klarić i Vedriš, Građansko pravo, 624 i sudskoj praksi (Vrhovni sud Republike Hrvatske, br. Rev - 3121/95 od 19. lipnja 1996., Revr-79/11 od 31. siječnja 2012. i Rev-399/94 od 20. rujna 1995.).

60 Čl. 25. st. 1. ZZR-a. 
rada i poslodavac za nju odgovara po načelu objektivne odgovornosti. Pritom se pod ozljedom na radu podrazumijeva ozljeda radnika nastala u prostoru poslodavca u kojemu obavlja rad, ili ga tijekom rada koristi, ili mu može pristupiti, odnosno $\mathrm{u}$ drugom prostoru koji nije prostor poslodavca, ali radnik u njemu obavlja rad. ${ }^{61}$ Primjenom odredbi Zakona o listi profesionalnih bolesti ${ }^{62}$ (u nedostatku posebnoga pojmovnog određenja prema odredbama ZZR-a) profesionalna bolest pojmovno se određuje kao bolest za koju se dokaže da je posljedica djelovanja štetnosti u procesu rada i/ili radnom okolišu, odnosno bolest za koju je poznato da može biti posljedica djelovanja štetnosti koje su u svezi s procesom rada i/ili radnim okolišem. Intenzitet štetnosti i duljina trajanja izloženosti toj štetnosti na razini je za koju je poznato da će prouzročiti oštećenje zdravlja. ${ }^{63} \mathrm{U}$ daljnjim odredbama ZOLPB-a ${ }^{64}$ profesionalnim bolestima smatraju se bolesti utvrđene u listi profesionalnih bolesti među kojima nisu navedene bolesti prouzročene mobingom na radu i u vezi s radom. Tako se $u$ skladu s navedenim pojmovnim određenjem ozljede na radu i profesionalne bolesti na štete prouzročene mobingom ne mogu primijeniti posebna pravila ZZR-a o objektivnoj odgovornosti za ozljede na radu i profesionalnu bolest koju je radnik pretrpio obavljajući poslove za poslodavca. Navedeno pravno shvaćanje prihvaćeno je i u sudskoj praksi, koju je prihvatio i Ustavni sud Republike Hrvatske, prema kojoj u okolnostima da se predmetne dijagnoze ne nalaze na listi profesionalnih bolesti, koja lista je propisana Zakonom o listi profesionalnih bolesti i po mišljenju ovog suda doista isključuje mogućnost priznavanja drugih bolesti kao profesionalnih oboljenja $^{65,66}$

ZSD $^{67}$ u poglavlju kojem uređuje zabranu diskriminacije, posebno (kao i ZR, pod neodgovarajućim naslovom Pravo na naknadu štete) ${ }^{68}$ uređuje da žrtva diskriminacije ima pravo na naknadu štete prema propisima koji uređuju obvezne odnose. U poglavlju kojim se uređuje postupak pred sudom, ZSD ${ }^{69}$ posebno ovlašćuje osobu koja tvrdi da je žrtva diskriminacije da podnese tužbu i zahtijeva naknadu imovinske i neimovinske štete prouzročenu povredom prava zaštićenih tim zakonom. U daljnjim odredbama ZSD uređuje i pretpostavke u kojima je žrtva diskriminacije ovlaštena zahtijevati da se presuda kojom je utvrđena povreda prava na jednako

61 Čl. 3. st. 1.t. 14. ZZR-a.

62 Zakon o listi profesionalnih bolesti, Narodne novine, br. 162/98., 107/07. (dalje: ZOLPB).

63 Čl. 2. st. 1. ZOLPB-a.

64 Čl. 3. st. 1. ZOLPB-a.

65 Upravni sud u Splitu, br. Uslzs-74/19-7 od 11. ožujka 2020. Istovjetno i u odluci Visokog upravnog suda Republike Hrvatske, br. Usž-1823/20-2 od 8. rujna 2020.

66 Ustavni sud Republike Hrvatske, U-III-6015/2020 od 19. svibnja 2021. (odlomak 7.).

67 Čl. 11. ZSD-a (3. poglavlje - Zabrana diskriminacije).

68 ZR odgovornost za štete nastale u radu i u vezi s radom uređuje odredbama čl. 107.-111. ZR-a, u poglavlju koje (14., Glave 2.) u odnosu na sadržaj ovih odredbi nosi neodgovarajući naziv „Naknada štete“. Isto tako, ZSD u 3. poglavlju, čl. 11. pod nazivom „Pravo na naknadu štete“. Sadržaj se ovih odredbi odnosi na uređivanje odgovornosti za štetu, dok je novčana naknada štete uz restituciju jedan od načina popravljanja štete. U tom smislu de lege ferenda poglavlje ZR-a s navedenim sadržajem trebalo bi nositi naziv „Odgovornost za štete nastale na radu ili u vezi s radom“, a ZSD-a „Pravo na popravljanje štete“.

69 Čl. 17. st. 1. t. 3. ZSD-a (5. poglavlje - Postupak pred sudom). 
postupanje na trošak tuženika objavi u medijima. Kako je riječ o šteti na radu ili u vezi s radom, te kako je poslodavac dužan zaštititi dostojanstvo radnika tijekom obavljanja poslova od postupanja nadređenih, suradnika i osoba s kojima radnik redovito dolazi u doticaj u obavljanju svojih poslova, odgovoran je i za štetu koju radnik trpi zbog diskriminacije na radu ili u vezi s radom, ${ }^{70}$ dok se kod odgovornosti za ove štete odgovarajuće primjenjuju opća pravila obveznog prava. ${ }^{71}$

\subsection{Odgovornost za štetu koja je radniku na radu i u vezi s radom prouzročena mobingom}

Prema odredbama ZR-a i ZZR-a radnik se posebno štiti od uznemiravanja samo ako je ponašanje kojim se radnik uznemirava prouzročeno nekim od osnova diskriminacije (vidi u radu pod 2.). ${ }^{72}$ Tako neželjeno ponašanje kojem je cilj ili je stvarna povreda dostojanstva radnika i koje je kod radnika prouzročilo strah, neprijateljsko, ponižavajuće ili uvredljivo okruženje, ali nije učinjeno zbog nekog od osnova diskriminacije, ne smatra se uznemiravanjem i radnik ne ostvaruje pravo na prekid rada u smislu odredbi kojima $\mathrm{ZR}^{73}$ posebno uređuje zaštitu dostojanstva radnika. Tek u okolnostima ako je takvo neželjeno ponašanje kojim se radnik uznemirava izravna prijetnja rizika za život i zdravlje radnika, prema odredbama ZZR-a, radnik ima pravo odbiti raditi i napustiti mjesto rada, sve dok poslodavac ne poduzme korektivne mjere. ${ }^{74}$ Zaštita od mobinga ne pruža se niti prema posebnom pravnom uređenju ZSD-a. U tim se postupcima ne odstupa od općih pravila parničnoga postupka o teretu dokaza (da je teret dokazivanja činjenica na kojima temelji svoj zahtjev na tužitelju).

Kako ZR, ZZR i ZSD svojim posebnim pravnim uređenjem ne pružaju zaštitu od mobinga, to se niti odgovornost za štetu po ovoj osnovi ne može sagledavati u skladu s odredbama kojima se navedenom normativom pruža posebna pravna zaštita od diskriminacije i uznemiravanja, već na obvezi poslodavca da radnika zaštiti od svih neželjenih loših ponašanja na radu i u vezi s radom, pa i onih koja nisu diskriminatorna, uvijek kada nalazi da takva ponašanja mogu biti prijetnja zdravlju, dostojanstvu i sigurnosti radnika na radu i u vezi s radom. Tako radnik koji je u uzročnoj vezi s takvim ponašanjem na radu ili u vezi s radom pretrpio štetu, može zahtijevati popravljanje te štete prema pravilima ZR-a o odgovornosti poslodavca za štetu koju radnik pretrpi na radu ili u vezi s radom, uz odgovarajuću primjenu općih pravila obveznog prava o odgovornosti za štetu.

Takvo pravno shvaćanje prihvaćeno je i u sudskoj praksi na polazišnim

70 Ako je riječ o privremenom zapošljavanju i šteti koju je ustupljeni radnik po ovoj osnovi pretrpio na radu ili u vezi s radom kod korisnika, odgovarajućom primjenom posebnih pravila o odgovornosti za štetu kod privremenoga zapošljavanja (čl. 51. st. 3. ZR-a) radniku bi uz agenciju kao poslodavca za štetu odgovarao i korisnik.

71 Čl. 11. ZSD-a.

72 Samo ako je prouzročeno zbog nekog od diskriminirajućih osnova iz odredbe čl. 1. st. 1. ZSD-a.

73 U tim okolnostima radnik ne ostvaruje prava iz odredbe čl. 134. ZR-a. U tom smislu nema različitih pravnih shvaćanja ni u sudskoj praksi (Vrhovni sud Republike Hrvatske, Revr1253/12 od 4. veljače 2014.).

74 Čl. 69. st. 4. ZZR-a. 
osnovama: mobingom se ugrožava dostojanstvo osobe. Takav oblik zlostavljanja odnosno šikaniranja na radnom mjestu ne uživa sudsku zaštitu prema Zakonu o suzbijanju diskriminacije. Radnik u tom slučaju ima pravo na naknadu štete zbog povrede prava iz radnog odnosa sukladno odredbi čl. 109. ZR/95 odnosno čl. 103. ZR/09, u kojem slučaju se primjenjuju odredbe ZOO-a kao općeg propisa obveznog prava. ${ }^{75} \mathrm{U}$ tim postupcima na radniku kao tužitelju teret je dokaza svih iznesenih činjeničnih navoda na kojima temelji svoj zahtjev za popravljanje štete. ${ }^{76}$

Kako se stranke u tim zahtjevima za popravljanje štete činjeničnim osnovu tužbe najčešće pozivaju da su bile diskriminirane, ali i da su bile izložene mobingu, u pravnoj se doktrini ističe da je sud u tim predmetima dužan o utemeljenosti zahtjeva raspraviti na temelju obje činjenične osnove. To znači da će se prilikom stvaranja zaključka je li tužitelj bio diskriminiran gledati u čemu se sastoji diskriminatorno ponašanje i s kojeg osnova s jedne strane, a potom postoje li elementi za naknadu štete nastalu mobingom, $s$ druge strane. ${ }^{77}$ Navedeno je pravno shvaćanje prihvaćeno i u sudskoj praksi. ${ }^{78}$

Kod odgovora na pitanje je li riječ o odgovarajućoj primjeni pravila koja uređuju izvanugovornu (deliktnu) ili ugovornu (kontraktnu) odgovornost za štetu u okolnostima kada odgovarajuća primjena tih pravila posebnim pravnim uređenjem o odgovornosti poslodavca za štetu prouzročenu radniku nije određena, nužno je navesti da ovisno o štetnoj radnji kojom je šteta prouzročena (ima li štetna radnja karakter povrede prethodno postojeće / najčešće ugovorne / obveze ili građanskopravnog delikta), poslodavac za štetu koja je radniku nastupila na radu ili u vezi s radom može odgovarati prema pravilima ugovorne (kontraktne) ${ }^{79}$ ili izvanugovorne (deliktne) ${ }^{80}$ odgovornosti za štetu. Iako se pravila o izvanugovornoj odgovornosti za štetu supsidijarno (ako u sklopu posebnoga pravnog uređenja o ugovornoj odgovornosti za štetu nije drukčije propisano $)^{81}$ primjenjuju i na ugovornu odgovornost, primjena jednih ili drugih pravila važna je i po osnovi mogućnosti oslobođenja od odgovornosti, i prema mogućnostima ugovornog proširenja, ograničenja i isključenja odgovornosti, tereta dokaza te opsega naknade (pravila o predvidivoj šteti kod ugovorne odgovornosti). Kad je riječ o odgovornosti za štetu koja je radniku na radu i u vezi s radom prouzročena mobingom, nužno je krenuti od pravne prirode radnog odnosa kao ugovornog odnosa. Pritom treba napomenuti da se pravila o ugovornoj odgovornosti za štete trebaju primjenjivati u svim okolnostima kada je radniku šteta nastupila posljedicom povrede prethodno postojeće obveze iz radnog odnosa od

75 Županijski sud u Zagrebu, Gž R-1708/16 od 20. prosinca 2016. Slično: Vrhovni sud Republike Hrvatske, Revr-410/2017-2 od 24. travnja 2019., Revr-729/2017-2 od 11. lipnja 2019., Revr2100/15-3 od 27. travnja 2016., Revr-434/14-2 od 23. ožujka 2016. Revr-434/14-2 od 23. ožujka 2016. i Revr-344/14-2 od 4. srpnja 2018.

76 Tako i sudska praksa: Vrhovni sud Republike Hrvatske, Revr-147/2017-2 od 31. listopada 2018.

77 Milković, Diskriminacijski postupci u radnopravnim parnicama, 8.

78 Vrhovni sud Republike Hrvatske, Revr -291/14-2 od 22. rujna 2015.

79 Prema pravilima čl. 342.-349. ZOO-a uz supsidijarnu primjenu pravila čl. 1045.-1109. ZOO-a.

80 Dakle, prema pravilima iz odredbi čl. 1045.-1109. ZOO-a.

81 Čl. 349. ZOO-a. 
strane poslodavca, bez obzira na to je li ta obveza poslodavca utemeljena ugovorom o radu ili kao akcesorna obveza iz radnog odnosa, proizlazi iz drugih izvora koji uređuju taj sadržaj nakon što je utemeljen radni odnos. Obveza poslodavca da radnika zaštiti od svih neželjenih loših ponašanja na radu i u vezi s radom u svim okolnostima kada nalazi da takva ponašanja mogu biti prijetnja zdravlju, dostojanstvu i sigurnosti radnika na radu i u vezi s radom kao akcesorna obveza iz radnog odnosa proizlazi iz odredbi ZR-a i ZZR-a. U tom smislu šteta koja je radniku na radu i u vezi s radom prouzročena mobingom je šteta prouzročena povredom prethodno postojeće obveze. Zbog toga na ove štete odgovarajuće treba primijeniti pravila koja uređuju ugovornu (kontraktnu) odgovornost za štetu. Tek u okolnostima da se ta obveza poslodavca tumači kao obveza javnog prava, ${ }^{82}$ na ove štete odgovarajuće bi se mogla primijeniti opća pravila obveznog prava koja uređuju izvanugovornu (deliktnu) odgovornost za štetu. Sudska praksa i u tom slučaju navedenu obvezu poslodavca tumači kao obvezu javnog prava, pa odgovornost za štetu prouzročenu mobingom cijeni prema općim pravilima obveznog prava o izvanugovornoj odgovornosti za štetu.

Kada je riječ o odgovarajućoj primjeni pravila o subjektivnoj (kriterij krivnje) ili objektivnoj (kriterij uzročnosti) odgovornosti za štetu, treba reći da ako iz pravila odštetne odgovornosti za pojedine slučajeve odgovornosti ne proizlazi drukčije, poslodavac odgovara po kriteriju krivnje (prema kriteriju subjektivne odgovornosti). Isto tako, kada posebno pravno uređenje iz kojih primjena pravila o subjektivnoj odgovornosti proizlazi drukčije ne uređuju, odgovara se prema kriteriju pretpostavljene krivnje (štetnik odgovara za štetu ako je kriv, ali se njegova krivnja pretpostavlja). ${ }^{83}$ Odgovornost poslodavca za štetu koju je radnik pretrpio na radu ili u vezi s radom temelji se na objektivnoj odgovornosti (kriteriju uzročnosti) u okolnostima kada pravila posebnoga pravnog uređenja o odgovornosti poslodavca za štetu koju je radnik pretrpio na radu ili u vezi s radom, odnosno odgovarajuća primjena općih pravila obveznog prava o odgovornosti za štetu, ${ }^{84}$ upućuju na takvu odgovornost. Na primjenu objektivne odgovornosti (kriterij pretpostavljene uzročnosti) poslodavca za štetu koju je radnik pretrpio na radu ili u vezi s radom upućuju pravila ZZR-a kod ozljede na radu i profesionalne bolesti koju je radnik pretrpio obavljajući poslove za poslodavca (vidi u radu pod 3.). Pritom kod primjene posebnoga pravnog uređenja ZZR-a koja se odnose na odgovornost za štetu, treba naglasiti da osoba koja je u skladu s pravilima ovog Zakona ovlaštena za obavljanje poslova zaštite na radu, ${ }^{85}$ odgovara radniku za štetu prema subjektivnoj odgovornosti i to prema kriteriju pretpostavljene krivnje. Međutim, ako je radnik na radu ili u vezi s radom pretrpio štetu za koju mu prema odredbama ZZR-a odgovara ovlaštena osoba, poslodavac time nije oslobođen svoje odgovornosti za štetu, već za tu štetu prema pretpostavkama iz općih pravila obveznog prava o odgovornosti više osoba za istu štetu u okolnostima konkurencije uzroka solidarno odgovaraju poslodavac

82 Vidi, npr. Potočnjak i Grgurev, Odgovornost za neimovinsku štetu zbog diskriminacije na radu, 75 , iznesena kod odgovornosti za štetu prouzročenu diskriminacijom.

83 Čl. 1045. st. 1. i 2. ZOO-a.

84 Čl. 1045. st. 3. i 4. ZOO-a.

85 Čl. 3. st. 1. t. 13., čl. 82. st. 1. i čl. 26. st. 1. i 2. ZZR-a. 
i ovlaštena osoba. ${ }^{86}$ Izvan posebnoga pravnog uređenja ZZR-a koje se odnosi na objektivnu odgovornost, poslodavac odgovara radniku objektivnom odgovornošću i kada su ispunjene pretpostavke općih odredbi obveznog prava prema pravilima o objektivnoj odgovornosti za štete od opasne stvari (kao vlasnik stvari), odnosno opasne djelatnosti (kao osoba koja se tom djelatnošću bavi) ${ }^{87}$ i kada nisu ispunjene pretpostavke posebnoga pravnog uređenja (ZZR-a) o objektivnoj odgovornosti poslodavca za štetu koju je radnik pretrpio na radu ili u vezi s radom. Pritom kod primjene pravila posebnoga pravnog uređenja ZZR-a u odnosu na opća pravila ZOO-a o odgovornosti za štete od opasne stvari ili opasne djelatnosti, treba naglasiti da ZZR uređuje objektivnu odgovornost poslodavca za ozljede na radu i profesionalnu bolest koju je radnik pretrpio obavljajući za njega poslove, pa se na ove štete posebna pravila ZZR-a primjenjuju kao lex specialis u odnosu na opća pravila ZOO-a o objektivnoj odgovornosti. Tek na pitanja koja nisu uređena posebnim pravnim uređenjem ZZR-a odgovarajuće se primjenjuju opća pravila obveznog prava o objektivnoj odgovornosti. Budući da za štete prouzročene mobingom nije propisana objektivna odgovornost i na njih se ne mogu primijeniti posebna pravila ZZR-a o objektivnoj odgovornosti za ozljede na radu i profesionalnu bolest koju je radnik pretrpio obavljajući poslove za poslodavca (vidi u radu pod 3.1.) te opća pravila ZOO-a o objektivnoj odgovornosti za štete od opasne stvari (kada poslodavac odgovara kao vlasnik stvari), odnosno opasne djelatnosti (kada poslodavac odgovara kao osoba koja se bavi tom djelatnošću), primjenjuju se pravila o subjektivnoj odgovornosti za štetu i to o odgovornosti poslodavca prema kriteriju pretpostavljene krivnje. ${ }^{88}$

Kod privremenoga zapošljavanja putem agencija za privremeno zapošljavanje ZR posebno uređuje odgovornosti za štetu koju je ustupljeni radnik pretrpio na radu ili u vezi s radom kod korisnika. Prema tom posebnom pravnom uređenju ustupljeni radnik naknadu štete može potraživati od agencije ili korisnika u skladu s pravilima koja uređuju odgovornost poslodavca za štetu prouzročenu radniku. ${ }^{89}$

Ako je štetnu radnju prema radniku kao oštećenoj osobi prouzročio drugi radnik kod istog poslodavca, poslodavac je dužan pružiti radniku zaštitu od svih neželjenih loših ponašanja koja mogu biti prijetnja zdravlju, dostojanstvu i sigurnosti radnika na radu i u vezi s radom. ${ }^{90}$ Stoga za te štete odgovara poslodavac, ${ }^{91}$ odnosno agencija kao poslodavac ili korisnik ako je riječ o privremenom zapošljavanju. Ako je drugi radnik kao stvarni štetnik štetu prouzročio namjerno, oštećeni radnik je u dispoziciji svoj zahtjev za popravljanje štete postaviti protiv poslodavca, neposredno protiv

86 Pod pretpostavkama iz odredbe čl. 1107. ZOO-a.

87 U skladu s odredbama čl. 1063.-1067. ZOO-a.

88 Navedeno pravno shvaćanje nije dvojbeno u sudskoj praksi. Tako Vrhovni sud Republike Hrvatske, Revr - 721/2017-2 od 24. listopada 2018., te Županijski sud u Zagrebu, Gž R 404/16 od 12. siječnja 2017.

89 Čl. 51. st. 3. ZR-a. U tom smislu nema različitih pravnih shvaćanja ni u sudskoj praksi (Županijski sud u Osijeku, Gž R-582/2019-2 od 9. siječnja 2020.).

90 Čl. 7. st. 5. ZR-a.

91 Kod primjene pravila o odgovornosti poslodavca za štetu koju je radnik na radu ili u svezi s radom prouzročio trećoj osobi (čl. 1061. ZOO-a, čl. 109. ZR-a), pod trećom oštećenom osobom podrazumijeva i drugi radnik koji tom radnjom trpi štetu kod istog poslodavca. 
radnika kao stvarnoga štetnika ili istodobno protiv poslodavca i radnika, kada bi mu poslodavac i radnik kao stvarni štetnik za tu štetu odgovarali solidarno. ${ }^{92}$

Zaštitom prava osobnosti prema općim odredbama ZOO-a, ${ }^{93}$ između ostalog, štite se pravo na tjelesno i duševno zdravlje, ugled, čast i dostojanstvo određene osobe, pa se radnje koje obuhvaćaju pojmovno određenje mobinga u činjeničnoj osnovi tužbi za popravljanje štete po toj osnovi često vežu samo za neimovinsku štetu. Međutim, ponašanje obuhvaćeno pojmovnim određenjem mobinga štetna je radnja kojom se može prouzročiti i neimovinska i imovinska šteta (npr. troškovi liječenja osobe koja se razboljela kao posljedica mobinga). Slijedom navedenog, poslodavac odgovara radniku za neimovinsku i imovinsku štetu (ukupnu štetu) koja je radniku prouzročena mobingom, a takvo pravno shvaćanje prevladava u sudskoj praksi. ${ }^{94}$

\section{ZAKLJUČAK}

Iako u Republici Hrvatskoj mobing još uvijek nije odgovarajuće zakonski uređen, u radu analizirana normativa ZSD-a, ZR-a i ZZR-a svakako zahtijeva od poslodavca zaštitu dostojanstva radnika od svih postupanja koje se mogu podvesti pod pojmove diskriminacije, uznemiravanja, spolnog uznemiravanja, ali i šire od psihičkoga zlostavljanja (ponižavanja, maltretiranja) radnika na radnom mjestu koje pravna doktrina i sudska praksa pojmovno određuje mobingom. Međutim, iako je poslodavac prema navedenoj zakonskoj normativi dužan na radu i u vezi s radom zaštititi radnika od svih neželjenih ponašanja koja su prijetnja njegovu zdravlju, sigurnosti i dostojanstvu, pa tako i od mobinga, položaj radnika u ostvarivanju toga prava je otežan jer se u postupcima zaštite od mobinga radnik ne može pozvati na privilegiran položaj diskriminiranih osoba kod tereta dokazivanja kojeg posebno uređuju odredbe ZSD-a, niti je ovlašten na prekid rada prema posebnom uređenju ZR-a kojim se štiti dostojanstvo radnika od uznemiravanja i spolnog uznemiravanja. Tek u okolnostima ako je neželjeno ponašanje kojim se radnik uznemirava izravna prijetnja rizika za život i zdravlje radnika, shodno posebnom pravnom uređenju ZZR-a ovlašten je odbiti raditi i napustiti mjesto rada sve dok poslodavac ne poduzme korektivne mjere. Navedeno pravno uređenje de lege ferenda zahtijeva izmjene i dopune ZR-a kojima će se u skladu s već zauzetim pravnim shvaćanjima u pravnoj doktrini i sudskoj praksi pojam i zabrana mobinga na radu i u vezi s radom jasno odrediti na način kojim ovaj oblik zaštite dostojanstva radnika nije vezan za zabranjene osnove diskriminacije (izmjenama i dopunama odredbe čl. 7. st. 4. i 5. ZR-a), a radniku kod zaštite omogućiti prava propisana za zaštitu dostojanstva radnika kako po osnovi obveza poslodavca koji zapošljava najmanje 20 radnika na imenovanje osobe koja je osim njega ovlaštena primati i rješavati pritužbe vezane za zaštitu od mobinga (izmjenama i dopunama odredbe čl. 134. st. 2. ZR-a), roka u kojem su poslodavac ili osoba koju je on imenovao dužni ispitati pritužbu radnika i poduzeti sve potrebne mjere primjerene pojedinom slučaju radi zaštite od mobinga,

92 Riječ je o pasivnoj solidarnosti dužnika u smislu odredbe čl. 1107. st. 1. ZOO-a.

93 Čl. 19. ZOO-a.

94 Vrhovni sud Republike Hrvatske, Revr-438/2015-4 od 25. rujna 2019. 
ako utvrde da on postoji (izmjenama i dopunama odredbe čl. 134. st. 3. ZR-a) i po osnovi prava radnika na prekid rada (izmjenama i dopunama odredbe čl. 134. st. 4.-10. ZR-a).

Ako odgovornost za štetu koja je radniku na radu ili u vezi s radom prouzročena mobingom nije posebno pravno uređena, primjenjuju se pravila ZR-a o odgovornosti poslodavca za štetu koju radnik pretrpi na radu ili u vezi s radom, uz odgovarajuću primjenu općih pravila obveznog prava o odgovornosti za štetu. U nedostatku posebnoga pravnog uređenja odgovornosti za ove štete, pravna doktrina i sudska praksa je (uz odgovarajuću primjenu općih pravila o odgovornosti za štete) odgovorila na otvorena pitanja: štete na radu i u vezi s radom kao posebne pretpostavke odgovornosti, pasivne legitimacije u ovim postupcima, vrste i opseg štete čije je popravljanje radnik ovlašten zahtijevati te kriterija odgovornosti. Međutim, u pravnoj doktrini i sudskoj praksi i dalje je otvoreno pitanje vrste odgovornosti (je li riječ o odgovarajućoj primjeni općih pravila obveznog prava koja uređuju izvanugovornu (deliktnu) odgovornost za štetu ili pravila koja reguliraju odgovornosti za štetu zbog povrede prethodno postojeće obveze (ugovornu, kontraktnu / odgovornost). Posebna obilježja ove štetne radnje i sve veći broj postupaka koji se po toj osnovi vode pred sudovima de lege ferenda zahtijevaju izmjene i dopune ZR-a (dopunama odredbe čl. 111. ZR-a) kojim bi se odgovornost za te štete posebno uredila u skladu s rješenjima navedenim u ovom radu.

\section{LITERATURA}

1. Babić, Vera, Ivica Crnić, Irena Cvitanović, Viktor Gotovac, Marina Gašpar Lukić, Darko Milković, Ilija Tadić, Marija Zuber i Inga Žic. Veliki komentar novog Zakona o radu. Zagreb: Vaša knjiga, 2010.

2. Barić Punda, Vesna. „Načelo nediskriminacije - jedno od temeljnih načela zaštite ljudskih prava i sloboda“. Zbornik radova Pravnog fakulteta u Splitu 42, br. 1-2 (2005): 27-42.

3. Crnić, Ivica. „Odgovornost za štetu iz radnog odnosa i popravljanje te štete“. U: Radni odnosi u Republici Hrvatskoj, Željko Potočnjak (ur.) et al., 267-322. Zagreb: Pravni fakultet u Zagrebu i Organizator, 2007.

4. Direktiva Vijeća 2000/43/EZ od 29. lipnja 2000. o provedbi načela jednakosti jednakog postupanja prema osobama bez obzira na njihovo rasno ili etničko podrijetlo, Službeni list EU, br. 180, 19. 7. 2000.

5. Direktiva Vijeća 2000/78/EZ od 27. studenoga 2000. o uspostavi općeg okvira za jednako postupanje pri zapošljavanju i obavljanju zanimanja, Službeni list EU, br. 303, 02. 12. 2000.

6. Direktiva Vijeća 2004/113/EZ od 13. prosinca 2004. o provođenju načela jednakog postupanja prema muškarcima i ženama u pružanju usluga, Službeni list EU, br. 373, 21. 12. 2004.

7. Direktiva Vijeća 2006/54/EZ od 05. srpnja 2006. o provedbi načela jednakih mogućnosti i jednakih postupanja prema muškarcima i ženama u pitanjima zapošljavanja i rada, Službeni list EU, br. 204, 26. 07. 2006.

8. Gović Penić, Iris. „Nova sudska praksa na području uznemiravanja/ diskriminacije i mobinga“. Radno pravo br. 10 (2018): 3-14.

9. Klarić, Petar i Martin Vedriš. Građansko pravo. Zagreb: Narodne novine, 2009.

10. Kostelić Martić, Andreja. Mobing: psihičko maltretiranje na radnom mjestu. Zagreb: 
Školska knjiga, 2005.

11. Milković, Darko. „Diskriminacijski postupci u radnopravnim parnicama“. U: Zbornik radova Građansko pravo - sporna pitanja i aktualna sudska praksa - 2018., 1-30. Tuheljske Toplice: Vrhovni sud Republike Hrvatske i Pravosudna akademija, 2018.

12. Omejec, Jasna. „Zabrana diskriminacije u praksi Europskog suda za ljudska prava“. Zbornik Pravnog fakulteta u Zagrebu 59, br. 5 (2009): 873. -979.

13. Petričević, Anton i Davor Medarić. „Pravo radnika na dostojanstven rad i radno okruženje bez stresa“. Pravni vjesnik: časopis za pravne i društvene znanosti Pravnog fakulteta Sveučilišta J.J. Strossmayera u Osijeku 30, br. 2 (2014): 405 - 419.

14. Potočnjak, Željko i Ivana Grgurev. „Odgovornost za neimovinsku štetu zbog diskriminacije na radu“. U: Odgovornost za neimovinsku štetu zbog povreda prava osobnosti u vezi s radom - mobing, dostojanstvo, diskriminacija, izloženost štetnim utjecajima, ozljeda na radu, profesionalna oboljenja $i$ dr., ur. Petar Klarić, - Zagreb: Narodne novine, 2007.

15. Potočnjak, Željko. „Zabrana diskriminacije, uznemiravanja i spolnog uznemiravanja u radnim odnosima“. U: Radni odnosi u Republici Hrvatskoj. Željko Potočnjak (ur.) et al., 47-99. Zagreb: Pravni fakultet u Zagrebu i Organizator, 2007.

16. Pražetina Kaleb, Renata. „Oblici mobinga i sudska zaštita žrtava mobinga“. Policija $i$ sigurnost 21, br. 4 (2012): 823-836.

17. Šokčević, Svjetlana. „Zakon o zaštiti na radu s komentarima i tumačenjima“. Zagreb: TIM press, 2014.

18. Šokčević, Svjetlana. „Zaštita dostojanstva i zdravlja radnika - zaštita od maltretiranja na radu i u vezi s radom“. Sigurnost: časopis za sigurnost u radnoj i životnoj okolini 58, br. 1 (2016): 1-18.

19. Ustav Republike Hrvatske, Narodne novine, br. 56/90., 135/97., 8/98., 113/00., 124/00., 28/01., 41/01., 55/01., 76/10., 85/10., 5/14.

20. Upravni sud u Splitu, Uslzs - 74/19-7 od 11. ožujka 2020.

21. Ustavni sud Republike Hrvatske, U-III-4639/2005 od 5. svibnja 2006.

22. Ustavni sud Republike Hrvatske, U-III-1095/2014 od 21. rujna 2017.

23. Ustavni sud Republike Hrvatske, U-III-6791/2014 od 30. svibnja 2018.

24. Ustavni sud Republike Hrvatske, U-III-3519/2018 od 7. listopada 2020.

25. Ustavni sud Republike Hrvatske, U-III-6015/2020 od 19. svibnja 2021.

26. Ustavni zakon o pravima nacionalnih manjina, Narodne novine, br. 155/02., 47/10., 80/10., 93/11.

27. Vasiljević, Snježana i Mario Vinković. Temeljna prava i zabrana diskriminacije u praksi europskih i nacionalnih sudova. Zagreb: Narodne novine, 2019.

28. Vinković, Mario, Snježana Vasiljević i Iris Gović Penić. Priručnik o diskriminaciji i mobbingu na radnom mjestu. Zagreb: Udruga za pomoć i edukaciju žrtava mobinga, 2016.

29. Vrhovni sud Republike Hrvatske, Rev-399/94 od 20. rujna 1995.

30. Vrhovni sud Republike Hrvatske, Rev-3121/95 od 19. lipnja 1996.

31. Vrhovni sud Republike Hrvatske, Revr-552/05 od 28. prosinca 2005.

32. Vrhovni sud Republike Hrvatske, Revt-133/07 od 29. travnja 2008.

33. Vrhovni sud Republike Hrvatske, Revr-79/11 od 31. siječnja 2012.

34. Vrhovni sud Republike Hrvatske, Revr-1253/12 od 4. veljače 2014.

35. Vrhovni sud Republike Hrvatske, Revr-291/14-2 od 22. rujna 2015.

36. Vrhovni sud Republike Hrvatske, Revr-434/14-2 od 23. ožujka 2016.

37. Vrhovni sud Republike Hrvatske, Revr-2100/15-3 od 27. travnja 2016.

38. Vrhovni sud Republike Hrvatske, Revr-526/17-2 od 26. rujna 2017.

39. Vrhovni sud Republike Hrvatske, Revr-344/14-2 od 4. srpnja 2018.

40. Vrhovni sud Republike Hrvatske, Revr-721/2017-2 od 24. listopada 2018.

41. Vrhovni sud Republike Hrvatske, Revr-147/2017-2 od 31. listopada 2018. 
42. Vrhovni sud Republike Hrvatske, Revr-1761/2014-3 od 27. veljače 2019.

43. Vrhovni sud Republike Hrvatske, Revr-410/2017-2 od 24. travnja 2019.

44. Vrhovni sud Republike Hrvatske, Revr-729/2017-2 od 11. lipnja 2019.

45. Vrhovni sud Republike Hrvatske, Revr-438/2015-4 od 25. rujna 2019.

46. Vrhovni sud Republike Hrvatske, Revr-735/2015-2 od 13. studenog 2019.

47. Visoki upravni sud Republike Hrvatske, Usž-1823/20-2 od 8. rujna 2020.

48. Zakon o državnim službenicima, Narodne novine, br. 92/05., 140/05., 142/06., 77/07., 107/07., 27/08., 34/11., 49/11., 150/11., 34/12., 38/13., 377/13., 1/15., 138/15., 61/17., 70/19., 98/19.

49. Zakon o listi profesionalnih bolesti, Narodne novine, br. 162/98, 107/07.

50. Zakon o obveznim odnosima, Narodne novine, br. 35/05., 41/08., 125/11., 78/15., 29/18.

51. Zakon o parničnom postupku, Narodne novine, br. 53/91., 91/92., 112/99., 88/01., 117/03., 88/05., 2/07., 84/08., 96/08., 57/11., 148/11. - proč. tekst, 25/13., 28/13., 89/14., $70 / 19$.

52. Zakon o policiji, Narodne novine, br. 34/11., 130/12., 151/14., 33/15., 121/16., 66/19.

53. Zakon o radu, Narodne novine, br. 93/14., 127/17., 98/19.

54. Zakon o ravnopravnosti spolova, Narodne novine, br. 82/08., 125/11., 20/12., 138/12., $69 / 17$

55. Zakon o službenicima i namještenicima u lokalnoj i područnoj (regionalnoj) samoupravi, Narodne novine, br. 86/08., 61/11., 4/18., 96/18., 112/19.

56. Zakon o službi u Oružanim snagama Republike Hrvatske, Narodne novine, br. 73/13., 75/15., 50/16., 30/18., 125/19.

57. Zakon o suzbijanju diskriminacije, Narodne novine, br. 85/08., 112/12.

58. Zakon o zaštiti na radu, Narodne novine, br. 59/96., 94/96., 114/03., 100/04., 86/08., 116/08.,75/09., 143/12.

59. Zakon o zaštiti na radu, Narodne novine, br. 71/14., 118/14., 154/14., 118/14., 154/14., 94/18., 96/18.

60. Zakon o životnom partnerstvu osoba istog spola, Narodne novine, br. 92/14., 98/19.

61. Županijski sud u Osijeku, Gž R-582/2019-2 od 9. siječnja 2020.

62. Županijski sud u Zagrebu, Gž R-1708/16 od 20. prosinca 2016.

63. Županijski sud u Zagrebu, Gž R - 404/16 od 12. siječnja 2017. 


\section{Trpimir Perkušić*}

Summary

\section{PROTECTION AND LIABILITY FOR DAMAGES CAUSED BY MOBBING AT WORK AND IN WORK-RELATED SITUATIONS}

The Croatian legal framework is still incomplete when it comes to the creation of a clear conceptual definition and related regulation on the protection from psychological abuse/humiliation, harassment of workers in the workplace (e.g. mobbing). It furthermore lacks a clear regulatory basis of liability for damages caused by mobbing at work and in work-related situations. Therefore, this paper analyzes these legal relations in the context of a broader framework that can be applied to them, and thus respond to the open questions in legal doctrine and case law. At the same time, according to the results of the conducted analysis, possible solutions are considered de lege ferenda.

Keywords: mobbing; protection against mobbing at work and in work-related situations; liability for damage caused by mobbing at work and in work-related situations.

* Trpimir Perkušić, mag. iur., Assistant, University of Split, Faculty of Law,; trpimir.perkusic@ pravst.hr. ORCID: https://orcid.org/0000-0003-4561-9926. 